\title{
DIAGNOSIS OF TOURISM ENHANCEMENT OF THE UNESCO WORLD HERITAGE ENSEMBLE OF APOSTOLIC CHURCHES OF ARMENIA
}

\author{
A. Sanasaryan ${ }^{1}$, M.J. Viñals ${ }^{1,2, *}$ \\ ${ }^{1}$ Universitat Politècnica de València, Spain - sanasaryananna@gmail.com, mvinals@upv.es \\ ${ }^{2}$ Research Centre PEGASO, Universitat Politècnica de València, Valencia, Spain
}

Commission II, WG - II/8

KEY WORDS: World Heritage Site, Public Use Management, Tourism Enhancement Tools, Armenia

\begin{abstract}
:
Among thousands of UNESCO World Heritage Sites around the world, three groups belong to the Republic of Armenia; Cathedral and Churches of Echmiatsin and the Archaeological Site of Zvartnots (2000), Monasteries of Haghpat and Sanahin (1996, 2000), and Monastery of Geghard and the Upper Azat Valley (2000). All of them are distinctive representatives of Armenian Apostolic Church. Their uniqueness lies in their historical origin (dating back to the 4th century), singular architectural style and their ability to provide spiritual support to Armenians from ancient times. Almost all of them are still used for their original (religious) purpose. Nevertheless, in some cases poor public visitation is observed. Being the first example of this kind of research in Armenia, the objective of this study is to analyse and make a diagnosis of the current condition of the sites regarding the public visitation and tourism uses, as well as to propose heritage enhancement tools to improve the physical and intellectual access to them. The methodology includes the combination of observational fieldwork, revision of scientific bibliography, as well as preparation of a complete heritage inventory of these sites. Assessments are performed both from the tourism point of view and for the intrinsic values of these monuments, following technical criteria. The results of this study attest to the tourism potential of those churches. Particularly, the Monastery of Geghard and the Cathedral of Echmiatsin are unique and of significant importance due to their accessibility, good conservation conditions and attractiveness.
\end{abstract}

\section{INTRODUCTION}

Armenia is a country located in the Southern Caucasus Mountains, between the Black Sea and the Caspian Sea, just in the northeast of the Armenian Highlands. It is a country with an ancient history dating back to the Bronze Age, and with a rich cultural heritage, which includes its distinctive alphabet and language, and its religion. It was the first country in the world to adopt Christianity as its official religion in the late 3rd or early 4th century (Stringer, 2005).

Inspired by the religion, the majority of the structures in Armenia, especially medieval churches, were built with distinctive architectural features, representing their unique style in the international arena. The religious, historical and natural values of some of those buildings were fundamental for their designation as UNESCO World Heritage Sites. These buildings are primarily places of worship where people meet to honour their faith and celebrate significant life events, but they are also treasure houses of heritage, history and community. Therefore, these places attain a great potential of attracting visitors, as well as providing them with an enjoyable and worthwhile experience.

An increasing number of people are visiting churches and other religious heritage sites around the world, thereby increasing the awareness of their significance as attractions (National Churches Trust, n.d.). For instance, English tourism statistics reveal that 55 $\%$ of all day trips include at least one visit to a cathedral or a church (Duff, 2009). According to the UNWTO (2011), up to 330 million tourists visit the world's key religious sites annually, and about 600 million national and international travels are carried out worldwide for religious purposes.
As stated by Aulet and Vidal (2018), these operational religious structures convey the age-old values linked to the identity of a territory, while reflecting on the relationship between the religious values and the monumental values of a place. Therefore, in the bases of this research lies the question if tourist activity in Armenian Apostolic Churches can be compatible with the existing activities.

As a result, the significant architectural and artistic features of these buildings, as well as the relationship between the religious significance along with the monumental value of these places are presented in this paper. Additionally, visits to churches can have economic value, as people will typically spend money on travel, food and other items as part of their day out, as well as on accommodation in case they overnight at the destination (Duff, 2009). Furthermore, tourist activities at religious sites constitute an important source of income for many faith institutions and organisations, generating funds for repairs and maintenance (Woodward, 2004).

Therefore, the objective of the present work was to make a diagnosis of the current situation of the UNESCO religious World Heritage Sites (Apostolic buildings) of Armenia to identify new compatible cultural and tourist activities to be developed. These Apostolic buildings, by their nature, are not commercially run attractions, but some initiatives related to the encouragement of the churches to adopt good 'visitor friendly' practices should be developed to increase the heritage awareness and appreciation for these churches. This paper will try to identify them.

\footnotetext{
* Corresponding author
} 


\section{METHODOLOGY}

The methodology applied in this study was based on qualitative methods. The diagnosis was carried out as a result of the successful completion of the following steps: data collection and classification from observational fieldwork, intrinsic and recreational assessment of the heritage elements, and analysis of the related recreational facilities.

In order to collect data about the heritage elements, we referred to the available scientific literature and the data from the websites. Direct observation of those religious buildings during the fieldwork was essential throughout the whole process of the study as well.

Then, the information gathered was organized following the inventory worksheets developed and proposed in the book Sustainable tourism and heritage enhancing and planning tools (Viñals et al., 2017), that covers different aspects of the inventory process and consist of 13 key sections.

For the assessment of the tourism values of the sites, we followed criteria suggested by the worksheets, specifically, attractiveness, resistance, availability, feasibility, educational values and functionality.

Finally, having evaluated values of the elements, it became possible not only to identify the buildings that were ready to receive public visits (in terms of their current state and the opportunity for improvement), but also to develop general guidelines, in order to enhance their overall state and, thus, be ready for future visits.

\section{THE ARMENIAN APOSTOLIC HERITAGE}

\subsection{Armenian Apostolic Religion}

Armenian Apostolic Churches are the materialization of the national religion of Armenian people: the Armenian Apostolic Church. The name originates from the belief that Christianity was brought to the country by apostles Bartholomew and Thaddeus in the 1 st century.

According to Vardanyan (1998), in 301, with the effort of Gregory the Illuminator, the patron saint and first official head of the Armenian Apostolic Church, the pagan king of Great Armenia, Tiridates III, proclaimed Christianity as the state religion. Therefore, Armenia became the first nation in the world to adopt Christianity as its official religion. Since the first day of adoption, the Armenian nation has been faithful to the religion, thereby celebrating the 1,700th anniversary of adoption in 2001 .

This important step had an immense impact on the development of the country, especially on architecture. After the adoption of the new religion, the extensive church-building process took place. In fact, many centuries ago one of the capitals of Armenia of that time, Ani, was known as "the city of 1001 churches". Therefore, it is no surprise that the vast majority of historical monuments in Armenia are churches, which is the prime reason why all the UNESCO World Heritage Sites of Armenia are religious buildings.

Yet, Armenian churches are not just cultural representatives of the past. Currently, they serve to their initial purpose the same way as they did centuries ago, notwithstanding neither their state nor the antiquity.
The results of the population census of the Republic of Armenia in 2011 (National Statistical Service of the Republic of Armenia, 2013) state that $92.6 \%$ of the total population of the country are followers of the Armenian Apostolic Church. The 2018 report of U.S. Department of State on International Religious Freedom supports the former statement adding that "according to an International Republican Institute poll released in October [2018], $94 \%$ of the country's [Armenia's] population identify as Armenian Apostolic, 2 $\%$ as Catholic, $3 \%$ other, and $1 \%$ none" (United States Department of State. Bureau of Democracy, Human Rights, and Labor, 2018).

Finally, it is noteworthy, that Apostolic Churches and other religious buildings keep their significance as sacred spaces that function developing their original purposes and preserving intangible related values.

\subsection{Armenian Apostolic buildings}

Currently, Armenia holds about 1,051 Christian monuments in its possession (Unified website for publication of legal acts' drafts, 2017). Three groups of these Apostolic buildings are designated as UNESCO World Heritage Sites (UNESCO World Heritage Centre, n.d.):

1. Cathedral and Churches of Echmiatsin and the Archaeological Site of Zvartnots

2. Monasteries of Haghpat and Sanahin

3. Monastery of Geghard and the Upper Azat Valley.

Upon research, no explanations were found detailing the reasons behind the collective designation of the sites. It seems as if the current composition of the groups was based on their location, as the elements in the same group are located near each other (Figure 1). On the other hand, there is a historical connection among these heritage sites, as they somehow at some point were linked to St. Gregory the Illuminator.

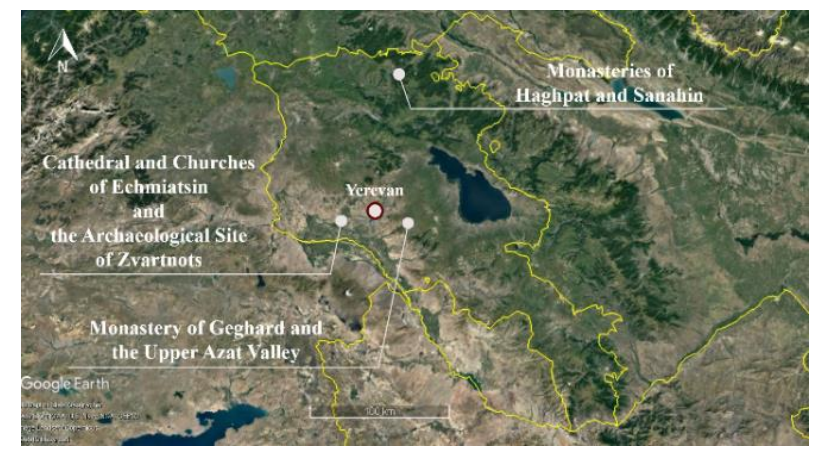

Figure 1. Location map of the Apostolic World Heritage Sites of Armenia (Cartographic base download from Google Earth, December 2019).

Every single one of these religious buildings has its remarkable characteristics. Despite their individuality, it is noteworthy, that they have some common features. Specifically, they have pointed or semi-pointed domes attached above arched ceilings, and their height often exceeds the length of the church. They are almost entirely made of volcanic stone (basalt or volcanic tuff).

The Cathedral and Churches of Echmiatsin are included in the first group. They are located in the Armavir province, near the capital, Yerevan. The whole complex consists of multiple buildings, the Cathedral being the main one. The Mother Cathedral of Echmiatsin (Figure 2) was built in the 4th century (301-303), and, according to Stokes (2009), is considered the oldest cathedral in the world. 


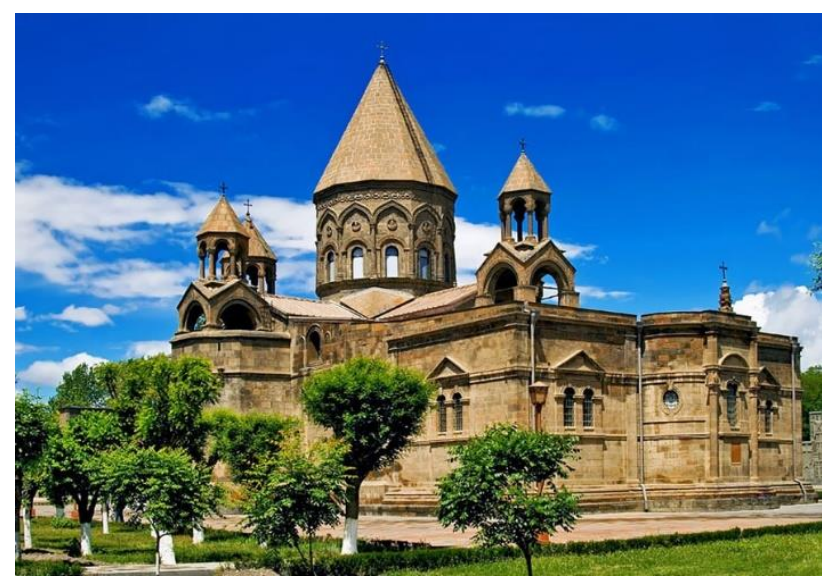

Figure 2. Cathedral of Echmiatsin. (OVigen Hakhverdyan n.d.

It is believed that St. Gregory the Illuminator had a vision of Jesus Christ descending from heaven and striking the earth with a golden hammer in order to show where the Cathedral should be built. Hence, the patriarch named the church "Etchmiadzin", which translates into "Ijav ([høul] - the Descent of) miatsiny ([úhudhईn] - the Only Begotten, Son of the God)," (Wainwright and Westerfield Tucker, 2006).

The Cathedral was originally constructed from wood having the layout of a basilica, but in 483 it was reconstructed and made into a cross-shaped building with a dome, and in the 7th century was rebuilt in stone. It was renovated a couple of times with belfries added in the 17th century and a sacristy built in the 19th century. Therefore, it combines styles of different periods of Armenian architecture.

Currently, the Cathedral is the administrative headquarter of the Mother See of Holy Etchmiatsin (the governing body of the Armenian Apostolic Church) and is the seat of the Catholicos of All Armenians.

The ruins of once colossal and one of a kind Zvartnots Cathedral (Figure 3) are situated $4-5 \mathrm{~km}$ to the West to the Cathedral of Echmiatsin. It took almost 20 years to build the church (643-652).

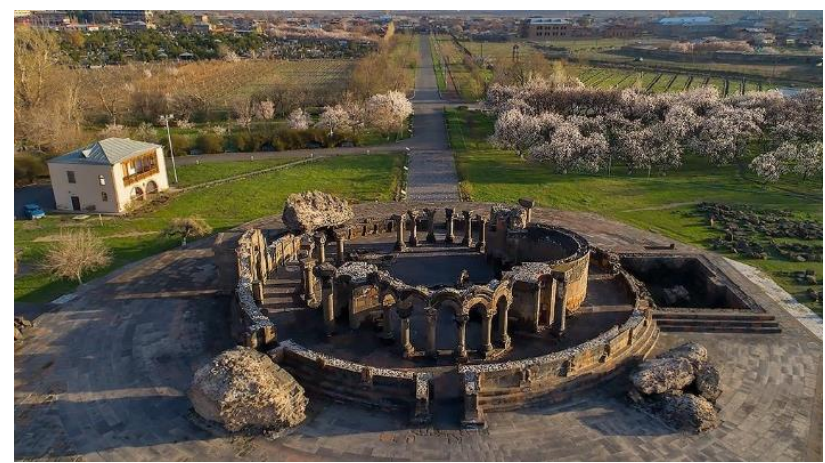

Figure 3. Cathedral of Zvartnots. @Andranik Keshishyan 2017.

It is believed (Khafadarian, 1959), that in this exact area the pagan King Tiridates III met St. Gregory the Illuminator for the first time after imprisoning him for 14 years in Khor Virap and agreed to proclaim Christianity as the state religion. According

(ii) - to exhibit an important interchange of human values, over a span of time or within a cultural area of the world, on developments in architecture or technology, monumental arts, town-planning or landscape design; to another belief, St. Gregory the Illuminator had his vision of Jesus Christ descending from heaven from this spot. Now, he, the Catholicos of all Armenians, lies in the heart of the Cathedral.

There is no indisputable explanation to the destruction of the Cathedral. The two most popular theories are the devastating earthquake that took place in 930 (Littlewood, 2011) and the destructive actions of the Arabs in the 80s of the 10th century (Khafadarian, 1959). Its ruins were discovered almost ten centuries later.

The recreation of its original image was presented by the renowned Armenian architect and architectural historian Toros Toramanian in 1905. According to Harutyunyan (1954), with Toramanian's reconstruction, Zvartnots appears as a threestorey construction, a uniform mass with the concentric axis. Its structural composition was a combination of round (rotunda) structure and four-altar forms. The three-storey building appeared to be pyramidal and was unprecedented in the Armenian architecture (Hakobyan, 2016).

In terms of the use, the former Cathedral no longer serves its religious purposes. People nowadays pay a visit mostly for educational and touristic purposes.

Along with the churches of St. Gayane, St. Hripsime, St. Shoghakat, St. Mariam Astvatsatsin and the Cathedral of Echmiatsin, the Archaeological site of Zvartnots was designated as World Heritage Site in 2000. The applied criteria for the designation of this group were $\mathrm{ii}^{1}$ and $\mathrm{iii}^{2}$.

The Monastery of Geghard (Figure 4) is situated in Kotayk province, at the head of the Azat valley, surrounded by towering rock cliffs. According to a popular belief, it was founded by St. Gregory the Illuminator in the 4th century at the site of a spring in a cave (Tovmasyan, 2016).

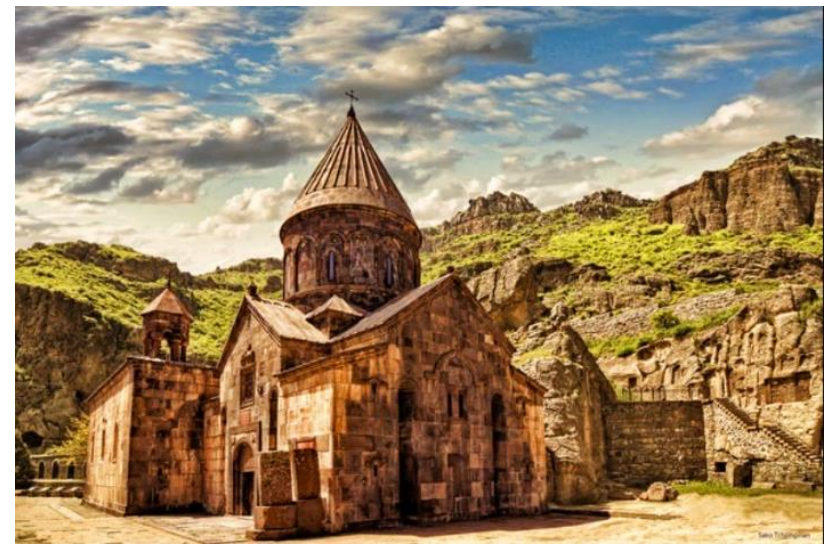

Figure 4. Monastery of Geghard and the Upper Azat Valley. (C)Sako Tchilingirian 2012.

As Tsovakan (1950) informs, previously the complex was called Airivank because 5 out of 7 churches forming the complex are carved into the mountain; "vank ([uluup] - monastery) Airi = Karairi ([punujnh] -of the cave).”

After the apostle Thaddeus brought the geghard ([qtinunn] Holy Lance, Spear) to Armenia, it was kept at Airivank and later

(iii) - to bear a unique or at least exceptional testimony to a cultural tradition or to a civilization which is living or which has disappeared; 
the name of the monastery was changed into Geghardavank; "vank ([цuip] - monastery) Gegharda ([Q.tnunnu] - of the Spear)". Currently, the Holy Lance is displayed in the Echmiatsin treasury.

Looking in the direction of the Monastery, only the main church St. Katoghike can be visible, while the rest of the churches can be explored only internally because they are located inside of the mountain.

During the 13th meeting of the UNESCO Committee for The Protection of Cultural Property in The Event of Armed Conflict (2018), it was "....decided to grant enhanced protection to the Monastery of Geghard and the Upper Azat Valley..." for its "... compilation with the condition of being of the greatest importance for humanity."

The Monastery of Geghard, along with the Upper Azat Valley, was inscribed in the UNESCO World Heritage List in 2000 (criterion ii).

The Monastery of Sanahin is located in the northern part of Lori Province. The Monastery complex (Figure 5) was founded by the King Abas Bagratuni in the 10th century (940-950). It took 300 years to finish the construction of the whole complex.

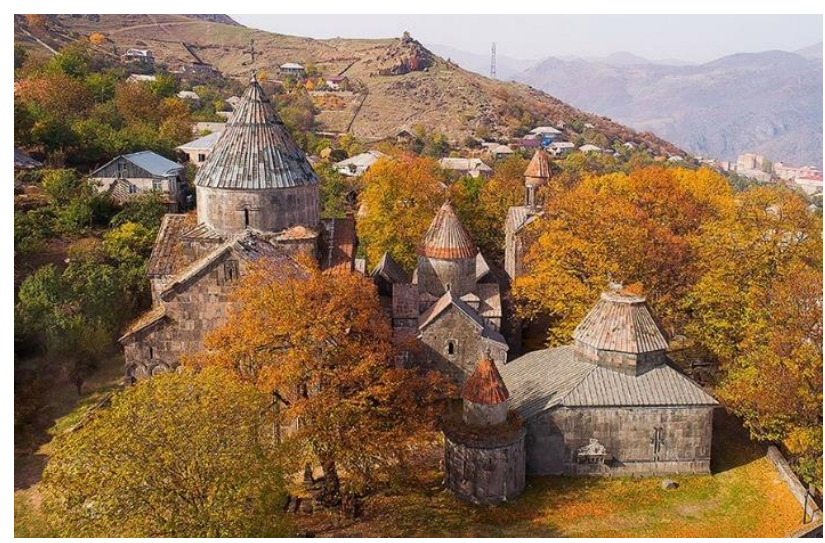

Figure 5. Monastery of Sanahin. @Andranik Keshishyan 2017.

It is believed that the monastic complex was built on a pagan temple after St. Gregory the Illuminator placed a wooden cross over the ruins of the temple, in the 4th century. The complex got its name after the Monastery of Haghpat was constructed. Although both monastery complexes were constructed in the same period, people wanted to specify that the Monastery of Sanahin was built earlier. Therefore, upon looking at the Monastery of Haghpat from the Monastery of Sanahin they used to say, "Sa ([uu] - this one) na ([qu]]- than that one) hin ([hhl] is older)".

The monastic complex consists of around 12 buildings. St. Astvatsatsin Church (928-944), being the oldest, is a centraldomed, cross-shaped example of Armenian medieval classical architecture, that reached its perfection as the main building of the complex. More than 50 khachkars ([huuspuphip] - cross-stones) that are spread in the area, are considered among the best examples of medieval Armenian sculpture (UNESCO, n.d.).

The Monastery of Haghpat (Figure 6) is located near the Monastery of Sanahin in the Haghpat village. It was founded in the 10th century (947-991) by the King Ashot III the Merciful, who was the son of the King Abas Bagratuni.

3 (iv) - to be an outstanding example of a type of building, architectural or technological ensemble or landscape which illustrates (a) significant stage(s) in human history;

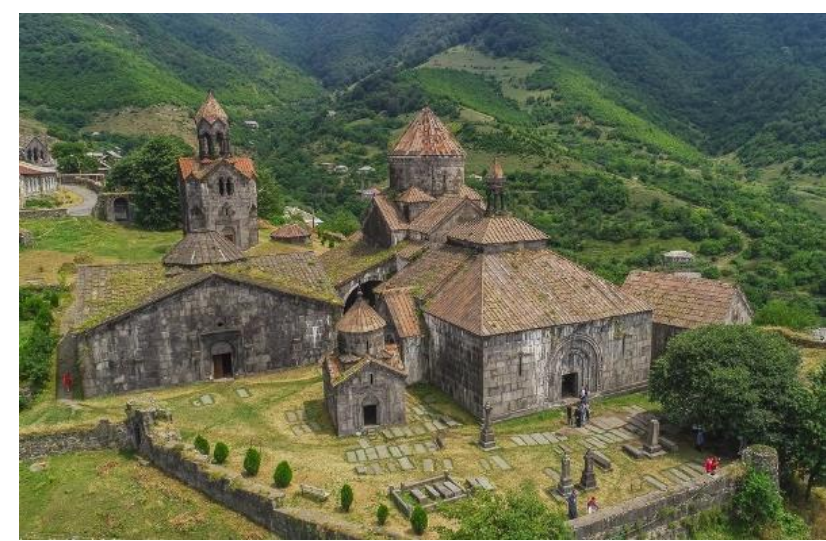

Figure 6. Monastery of Haghpat. @Andranik Keshishyan 2017.

St. Nshan Church is the oldest monument in the complex. The church is a rectangular domed construction, slightly elongated from east to west, with an internal cross-shaped plan. The central dome rests on four massive pillars in the side walls. Distinguished by its integrated interior and vast dominating dome, the church is a complete and brilliant example of a new stylistic trend of Armenian architecture in the 10th and 11th centuries. The earliest layer of the frescos in the main apse has survived, with its main composition of Jesus enthroned. Scenes of the annunciation, birth and baptism were painted on the lower part. Haghpat and Sanahin are one of a very few monasteries that have illustrations on the walls.

Due to the geographical and historical connection between the monastery complexes, most of the time it is difficult to imagine them separately; visitors of Sanahin will also stop by Haghpat, and vice versa.

At one point, both of them were important spiritual centres, serving as a place for education and spiritual shelter for around 500 priests and monks (Stepanosi, 1885), which is significantly more than there are in the entire country as of today. Currently, both monastery complexes maintain their original religious practices and are open for public visits. Additionally, the breathtaking mountain scene of Haghpat Monastery is noteworthy.

Together with the Monastery of Haghpat, the Monastery of Sanahin was included in the UNESCO World Heritage List in 1996. However, the extension was made in 2000 with the selection criteria ii, $\mathrm{iv}^{3}$.

\section{RESULTS}

For this research, the intrinsic value of the Apostolic Churches was not analysed in-depth because their significance had already been recognised at the international level as UNESCO World Heritage Sites. However, the tourism assessment of these assets was addressed in order to know their potential for visiting activities. For this analysis, the tourism criteria proposed by Viñals et al. (2017) were applied, such as Attractiveness, Fragility vs. Resistance, Accessibility, Availability, Feasibility, Educational values and Functionality. Additionally, results from previous research works have been included (Sanasaryan, 2019). 
An analysis of Strengthens, Weakness, Opportunities and Threats (SWOT) was applied to have a diagnosis of these heritage groups following the general approaches (territory, infrastructures and accessibility, facilities, tourism services, tourism values, legal framework and governance). This process facilitates the identification of further actions.

Firstly, it should be noted that unlike any other structure around the world, the architectural style of those buildings belongs to Armenian (ecclesiastical) Architecture. Individually, they have a different religious intent however, their unity represents the Armenian religion.

Regarding the attributes, there are mainly two kinds of buildings in those three groups: monasteries and churches. Typical to the majority of their kinds, these churches were built in urban areas, where they were more accessible to the believers and where religious activities were performed. The monasteries, however, were built in remotely isolated areas, as if merged into nature, so as to be hidden from the enemies, and served as a residence and educational shelter for the monks (Toramanian, 1989). However, the location of each of those heritage elements was not selected randomly.

According to the official designation of the UNESCO dossier, the historical site that occupies the most surface is the Archaeological site of Zvartnots (18.8 ha), while Monastery of Haghpat occupies the least area (0.75 ha).

In terms of local accessibility (from the capital city, Yerevan), the least accessible one is the furthest site (Monastery of Haghpat); not only because there are not any buses that run directly from Yerevan to Haghpat, but also because three different means of transportation have to be changed to reach Haghpat (Reynolds, 2016). Although all heritage elements have interstate and regional roads leading to them, the main issue comes with the long distance from the capital, poor quality of the roads and, in case of self-organised trips, scarce frequency of the public transportation.

A thorough analysis of the current condition of the sites revealed that in comparison to their initial state (when they were built), their general conservation condition is acceptable due to timely restoration works performed in different periods (mostly in the 20th century, funded by the Soviet government). A thorough observation of the dates and criteria of restoration works implies that there were no scheduled restorations. Therefore, the restoration works were carried out in relevance to the urgency and the budget at the time.

The most common sources of the damage were robberies, attacks of the enemies' army, as well as natural disasters, especially earthquakes. Due to high humidity levels in the area, the Monastery of Sanahin is almost entirely covered with vegetation. In the past, the latter served as a natural shelter, because it kept the buildings safe from the enemy. However, today high humidity levels combined with the lack of maintenance put the sites at risk.

Since the Monastery of Geghard and the Archaeological site of Zvartnots are known by their unique construction techniques and exclusive styles, they seem to be more scientifically recognised than the rest of the heritage sites. Nevertheless, all heritage sites provide significant scientific knowledge, specifically in the fields of History, Architecture and Archaeology, as well as in Religious issues.
As for the ownership, all heritage sites, except for the Archaeological site of Zvartnots, are under private ownership of the Armenian Apostolic Holy Church. The Archaeological site is under state ownership and is situated on the territory of Zvartnots Historical and Cultural Museum-Reserve, which holds all the historical references like pictures, plans etc. that unveil the story of Zvartnots. The heritage sites are managed under direct management model.

A weak point in tourism services is indicated by the small number of hotels and restaurants near the sites, and by the overall lack of well-organised service-providing companies that offer hospitality services. They need improvements in the quality of the facilities offered at the destination.

Concerning the current visits, the Cathedral of Echmiatsin is closed for restoration works. The Archaeological Site of Zvartnots can be accessed on the days when the MuseumReserve is open. The entrance to the Museum-Reserve, however, requires a fee. For the rest of the heritage sites, no official data are specifying any schedules of the religious services available on the web. In general, all churches are open to the public.

The tourism frequentation flow is especially heavy in Geghard, which is a major issue for the site. Among the rest, Geghard is famous for its well-preserved architectural uniqueness both with locals and tourists. In addition to that, it is one of the most widely offered attractions by tourism providers. Therefore, particularly during high season (summer), the flow of visitors never actually stops. The latter, on the other hand, has an essential (positive) socio-economic influence on local communities.

Currently, all the sites possess the basic minimum of visitation facilities, such as public restrooms, informative panels, benches etc., that are essential for facilitating visits for the general public. In addition to that, souvenir shops can be found near all heritage sites, where tourists can buy food, especially, traditional desserts, and products of the region. However, the lack of inclusive facilities prevents people with disabilities and special needs from visiting the sites. Therefore, most of the sites need to be enhanced in the sense of on-site accessibility.

\section{DISCUSSIONS AND CONCLUSIONS}

It should be noted that this is the first time that Armenian Apostolic Churches were studied so thoroughly in terms of their current state and identification of their tourism potential, as well as the enhancement and improvement measures for the public use of these churches.

The results of the diagnosis reveal that the heritage sites were passed down to the current generation in different states; therefore, the enhancement measures need to be implemented by providing an individual approach.

However, before carrying on with the enhancement tools for public visitation, one must make sure that the heritage conservation and protection are guaranteed, to ensure their physical preservation, good conditions and maintenance. Although legal protection tools exist at the national and international level, the technical tools conservation can be further improved. Moreover, to create sufficient outcomes two strategic lines are identified; improvement of general conservation conditions of these heritage buildings, and improvement of their protective means. 
In terms of general conservation, Heritage Conservation Plan should be drafted and executed, which includes Heritage Conservation and Restoration Standards. This step is essential for the preservation of the current state of the heritage and should not be skipped. Recognizing individual needs of heritage sites, restoration works should follow following the Restoration Standards. This plan must also include measures with respect to the physical protection against natural hazard (as the region is located in an active seismic area) and human activities (because of the high daily flow of visitors). Other impacts are related to the uncontrolled growth of vegetation on the walls and roofs and to the high levels of humidity affecting the buildings (case of Monasteries of Sanahin and Haghpat, Geghard).

After having assured that these measures are considered, the actions towards tourism enhancement can be taken. Then, the improvement of physical access by adapting the elements of the heritage and the surroundings for the public visit and some facilities must be planned. Additionally, to facilitate intellectual access, it is necessary to provide tools, such as an Interpretation Program. And finally, identifying governance issues for visitor management.

It is noteworthy that no data about the flow of visitors exist. Then, statistical data about visits should be collected and analysed regularly. This will help get the general image of the visitor profile, personality traits, needs, motivations, expectations, etc., therefore customising the enhancement actions according to the results.

To improve physical access, firstly Recreational Carrying Capacity of individual buildings should be estimated. The acceptable number of people indoors should be assessed, and by no means should it be exceeded in a way that can affect the properties.

Regarding the road infrastructure and facilities, the quality of the roads should also be improved, paying special attention to the local roads. Designating parking areas for cars and buses, taking into consideration the distance from the site, will ensure the access to the sites is possible. Sometimes there is no specific area allotted to parking, so the drives park wherever it is convenient for them. As a result of the intrusion of the cars in the viewshed, the overall landscape loses its beauty. Hence, there should be standards for the parking distance from the sites. This way the cars will not break the overall spirit of the place.

Concerning the transportation system, it will be necessary to make the information user-friendly to facilitate access to the heritage elements. The information displays at bus stops should also be repaired, updated and translated in foreign languages, even be digitalised in official websites in order to be accessed from smart devices.

It is noteworthy that the universal accessibility inside the buildings and their surroundings is not a common experience in Armenia. Although not neglected in the past, in most cases, the construction of inclusive facilities was not approached scientifically; for instance, the angles and levels of the ramps are not usually taken into account during the construction processes, making them not serve to their purpose. Therefore, standards for universal accessibility should be set and followed, applying individual approaches to each site if needed. The changes should be undergone with the least possible impact on the site and the possibility of future alterations, meaning that the integrity and the overall spirit of the place should stay intact.
Apart from that, an advanced Heritage Interpretative Program for facilitating the knowledge and a quality experience on the heritage sites (interpretive guides, signage system, information and interpretive materials, etc.) should be developed. Additionality, an official website for these sites should be created to provide overall information on the access, significance of the places, heritage knowledge and upcoming events, among others.

In order to revive the appreciation of the natives towards the heritage sites, Awareness Campaigns are strongly suggested.

To stimulate the improvement of the quality of customer services, training programmes for people working in the tourism sector are proposed. Specifically, the ones specialised in tourism communication and interpretation skills.

The last strategic line will help settle management issues. Firstly, it is necessary to draft, develop and implement a General Management Plan, which generally includes management solutions for building maintenance (Heritage Conservation and Protection Plan) and public use (Visitor Management Plan). A close eye should be kept on the performance of the restoration works. Regular maintenance reduces the risk of expensive largescale repairs (Historic England, 2019). They should be performed and completed in a timely manner. In addition to the main points, the Visitor Management Plan should also include emergency evacuation measures to face possible earthquakes and other hazards. Otherwise, in case of emergency and no Evacuation Plan, the visitors of (especially) Geghard will be helpless.

These actions should be taken into consideration in the official tourism planning in the partnership and consent of the Apostolic Church in a general participatory framework where all the interested stakeholders are involved.

In terms of their current state, the ability of improvement and the tourism potential of those heritage sites, the enhancement of the Monastery of Geghard and the Cathedral of Echmiatsin is concluded to take less effort. The one that needs the most urgent attention in the overall enhancement is the Monastery of Haghpat.

As a result, it can be concluded that the issues associated with visitors attending religious sites in Armenia have been underestimated. Visiting activities, together with the wide geographical spread and local distinctiveness and originality of the Apostolic heritage assets, suggest that church tourism offers a viable tourism opportunity for Armenia.

As a final reflection, it should be noted that the most common limitation faced in the process of carrying out the current research was connected to the availability of the scientific data. Most of the Armenian bibliographic references on the heritage sites discussed in this paper belong to the past century. They do, of course, maintain their invaluable contribution to the science; however, the unavailability of scientific documents published over the course of the past 20 years is quite disturbing. The limited access to the existing ones is another disadvantage. Therefore, the digitalisation of all the existing scientific bibliography is suggested, and, most importantly, regular researches about Armenian heritage are highly encouraged.

Calling ourselves "The Museum under the sky", we should take good care of the "exponents" we hold. Therefore, a simple act of care will contribute to the preservation of unique masterpieces that Armenia holds and show our gratitude to history. 


\section{REFERENCES}

Aulet, S., Vidal, D., 2018: Tourism and religion: sacred spaces as transmitters of heritage values. Church, Communication and Culture, 3 (3), 237-259.

Duff, A., 2009. Unlocking the Potential of Church Tourism. Tourism Insights.

Hakobyan, Z., 2016. Armenian early medieval sculpture (4th-7th centuries). YEREVAN, YSU press, ISBN 978-5-8084-2140-0. ysu.am/files/Haykakan_vaghmijnadaryan_qandaky.pdf

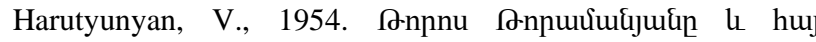

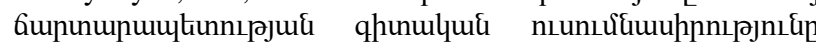

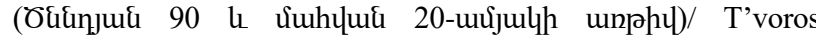
T'voramanyany yev hay chartarapetut'yan gitakan usumnasirut'yuny (Tsnndyan 90 yev mahvan 20-amyaki arrt'iv).

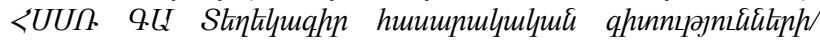
HSSRR GA Teghekagir hasarakakan gitut'yun, (5), 61-78. http://basss.asj-oa.am/970/1/1954-5(61).pdf

Historic England, 2019. Maintenance and Repair.

Khafadarian, K., 1959. 2umprang: (2hunnnnıpjnı\&uitn)/

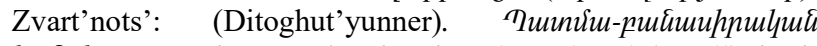
huiqnku/Patma-banasirakan handes, (4), 174-194. http://hpj.asjoa.am/72/1/59-4(174).pdf

Littlewood, A., 2011. Armenia and Nagorno-Karabagh. Canadio-Byzantina, 34-43.

National Churches Trust, n.d. Opening for visitors. https://www.nationalchurchestrust.org/working-what-you-havethings-do-now/opening-visitors (18 January 2020)

National Statistical Service of the Republic of Armenia, 2013. Table 5.4 Population (urban, rural) by Ethnocity, Sex and Religious Belief. Results of 2011 population census of the Republic of Armenia, Yerevan, 273-279.

Reynolds, A., 2016: Getting to Haghpat and Sanahin by public transport. https://www.lostwithpurpose.com/getting-haghpatsanahin-armenia-public-transport/ (19 June 2019).

Sanasaryan, A., 2019. Providing tourism enhancement guidelines for UNESCO World Heritage Sites of Armenia, Universitat Politècnica de València.

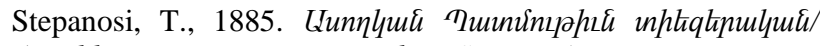
Asoghkan Patmut'iwn tiyezerakan, St Petersburg.

Stokes, J., 2009. Encyclopedia of the Peoples of Africa and the Middle East, Infobase Publishing.

Stringer, M. D., 2005. A Sociological History of Christian Worship. Cambridge: Cambridge University Press.

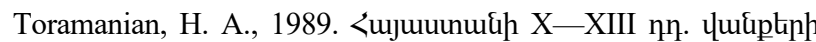

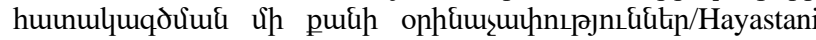
X-XIII dd. vank' eri hatakagtsman mi k'ani orinach'ap'ut'yunner.

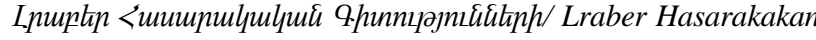
Gitut'yunneri, (2), 45-50, ISSN 0320-8117. http://lraber.asjoa.am/3725/1/1989-2(45).pdf
Tovmasyan, G.R. 2016. Religious tourism development bases and perspectives in the Republic of Armenia. publikacia.net. https://publikacia.net/archive/uploads/pages/2016_1_3/01.pdf (15 March 2020)

Tsovakan, N.V., 1950. Ujnhluup quर्u Qtinupnuj

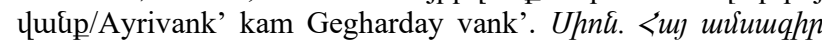

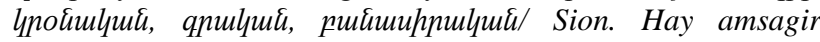
kronakan, grakan, banasirakan, 24(1), 23-26. http://sionj.asjoa.am/5487/1/23-26.pdf

UNESCO, n.d. Monasteries of Haghpat and Sanahin. https://whc.unesco.org/en/list/777/ (08 June 2019)

UNESCO Committee for the Protection of Cultural Property in the Event of Armed Conflict, 2018. Requests for the granting of enhanced protection. Paris, UNESCO Headquarters, C54/18/13.COM/12

https://unesdoc.unesco.org/ark:/48223/pf0000370925

UNESCO World Heritage Centre, n.d. Armenia. https://whc.unesco.org/en/statesparties/am (08 June 2019)

Unified website for publication of legal acts' drafts, 2017.

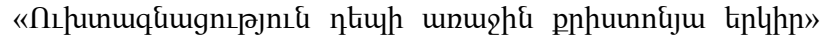

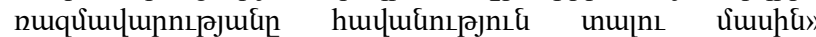

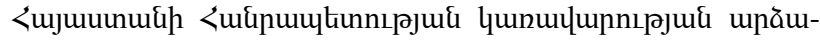

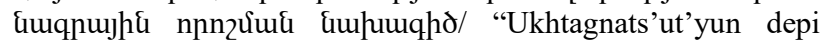
arrajin k'ristonya yerkir" rrazmavarut'yan havanut'yun talu masin" HH karravarut'yan ardzanagrayin voroshman nakhagits. https://www.e-draft.am/en/projects/229/about

United States Department of State. Bureau of Democracy, Human Rights, and Labor, 2018. International Religious Freedom Report for 2018. Armenia 2018 international religious freedom report.

UNWTO, 2011. Religious Tourism in Asia and the Pacific. https://www.e-unwto.org/doi/pdf/10.18111/9789284413805 (15 June 2019)

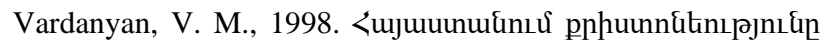

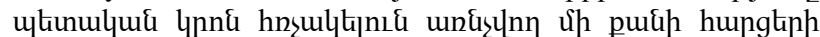
2nın// Hayastanum k'ristoneut'yuny petakan kron hrrch'akelun arrnch'vogh mi k'ani harts'eri shurj. Inwpkn <umunulumlu氏

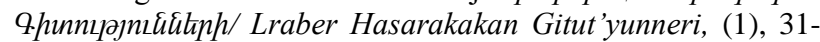
39, ISSN 0320-8117. http://lraber.asj-oa.am/1996/1/19981(31).pdf

Viñals, M.J, Mayor, M., Martínez-Sanchis, I., Teruel, L., AlonsoMonasterio, P. \& Morant, M., 2017. Sustainable Tourism and Heritage. Enhancing and Planning tools. Ed. Universitat Politècnica de València,

Wainwright, G. and Westerfield Tucker, K.B. (eds.), 2006. The Oxford History of Christian Worship. Oxford University Press.

Woodward, S.Ch., 2004. Faith and tourism: Planning tourism in relation to places of worship. Tourism and Hospitality Planning \& Development, 1(2), 173-186. 